\title{
Antipredator benefits of nest-site selection in Black-legged Kittiwakes
}

\author{
Heidi M. Regehr, Michael S. Rodway, and William A. Montevecchi
}

\begin{abstract}
We investigated the relationship between nest-site characteristics and breeding performance of Black-legged Kittiwakes (Rissa tridactyla) on Great Island, Newfoundland, during 2 years of extreme predation pressure. The nest-site feature most consistently associated with egg and chick survival was rock overhang above the nest. The presence of rock projections beside nests was positively correlated with success in 1993, and rock protrusions below the nest were not associated with breeding success in either year. Central position in the colony was positively correlated and nest density negatively correlated with success in 1992. Consistent differences in chick production among colony regions reflected differences in large-scale cliff structure and predator accessibility. This study implicates large- and fine-scale aspects of nest-site selection by Black-legged Kittiwakes, with large-scale cliff structure being the most important.
\end{abstract}

\begin{abstract}
Résumé : Pendant 2 ans, nous avons étudié la relation entre les caractéristiques des sites de nidification et la performance à la reproduction chez des Mouettes tridactyles (Rissa tridactyla), à Grande-île, Terre-Neuve, au cours d'une période de très forte pression de prédation. La caractéristique associée le plus étroitement avec la survie des oeufs et des oisillons était la présence d'un rocher en surplomb au-dessus du nid. Les projections de rocher aux côtés des nids ont été en corrélation avec le succès de la reproduction en 1993, mais les avancées de rocher sous les nids n'influençaient pas le succès de la reproduction au cours de l'une ou l'autre année. En 1992, une position centrale au sein de la colonie s'est avérée en corrélation positive avec le succès de la reproduction, alors que la densité des nids était en corrélation négative. Nous avons constaté que des différences persistantes dans la production des oisillons d'une région à l'autre reflétaient la structure grossière des falaises et l'accessibilité des prédateurs aux nids. Cette étude décrit des aspects à grande et à petite échelles de la sélection d'un site de nidification che z la Mouette tridactyle et la structure générale des falaises représente le caractère le plus important.

[Traduit par la Rédaction]
\end{abstract}

\section{Introduction}

Predation plays an ultimate role in the evolution of nest-site selection (Montevecchi 1978; Buckley and Buckley 1980; Parrish 1995). Most seabird species nest on islands that are free from terrestrial predators, and in colonies, where predator-defense tactics such as vigilance, mobbing, and swamping are effective against avian predators (Lack 1968; Wittenberger and Hunt 1985). Nesting habitat may provide further protection from predators, and adaptations for burrowand cliff-nesting have evolved in some species (Cullen 1957; Buckley and Buckley 1980). Fine-scale characteristics that differentiate individual nest sites within habitats, such as amount of cover for ground nesters, may also serve as protection from predators (Buckley and Buckley 1980; Miyazaki 1996). Differences in nest-site quality can lead to competitive assortment of breeding birds, so that the highest quality birds occupy the best sites (Coulson 1968; Montevecchi 1978; Nelson 1978; Gochfeld 1980).

Cliff-nesting has presumably evolved in Black-legged Kitti-

Received February 18, 1997. Accepted January 7, 1998.

H.M. Regehr, ${ }^{1}$ M.S. Rodway, ${ }^{1}$ and W.A. Montevecchi. Department of Biology, Memorial University of Newfoundland, St. John's, NF A1B 3X9, Canada.

${ }^{1}$ Present address: Department of Biological Sciences, Simon Fraser University, Burnaby, BC V5A 1S6, Canada. wakes (Rissa tridactyla) for defense against predators (Cullen 1957). Despite this adaptation, nest predation can be an important factor affecting breeding success (e.g., Hatch et al. 1993; Regehr and Montevecchi 1997). Predation risk has been associated with cliff structure, since nests on steep, vertical cliffs are less heavily preyed upon than nests on gradual or stepped cliffs (Barrett and Runde 1980; Roberts 1988; Chapdelaine and Brousseau 1989; Neuman 1994). Antipredator benefits of finer scale nest-site characteristics have not been examined in kittiwakes. Previous studies describing the benefits of social and physical nest-site characteristics have been conducted in situations where predation was minimal or not occurring (Coulson 1968; Squibb and Hunt 1983; Coulson and Thomas 1985; Olsthoorn and Nelson 1990; Porter 1990).

Intense predation at a Newfoundland kittiwake colony in 1992-1993 provided an opportunity to examine the antipredator benefits of nest-site characteristics. Food-stressed Great Black-backed Gulls (Larus marinus) and to a lesser extent Herring Gulls (L. argentatus) and Common Ravens (Corvus corax) took $90 \%$ of kittiwake eggs in each year (Regehr and Montevecchi 1997). Previous studies in 19691970, when food for Larus species was abundant, reported high breeding success and less than $5 \%$ of eggs taken by predators, mostly by ravens (Maunder and Threlfall 1972). Gulls (Larus) and ravens commonly prey on kittiwake eggs and chicks (e.g., Montevecchi 1979; Barrett and Runde 1980; Chapdelaine and Brousseau 1989; Hatch et al. 1993; Neuman 1994; Regehr and Montevecchi 1997), accessing nests from 
Fig. 1. Locations of study areas on Great Island, Newfoundland, in 1992 and 1993.

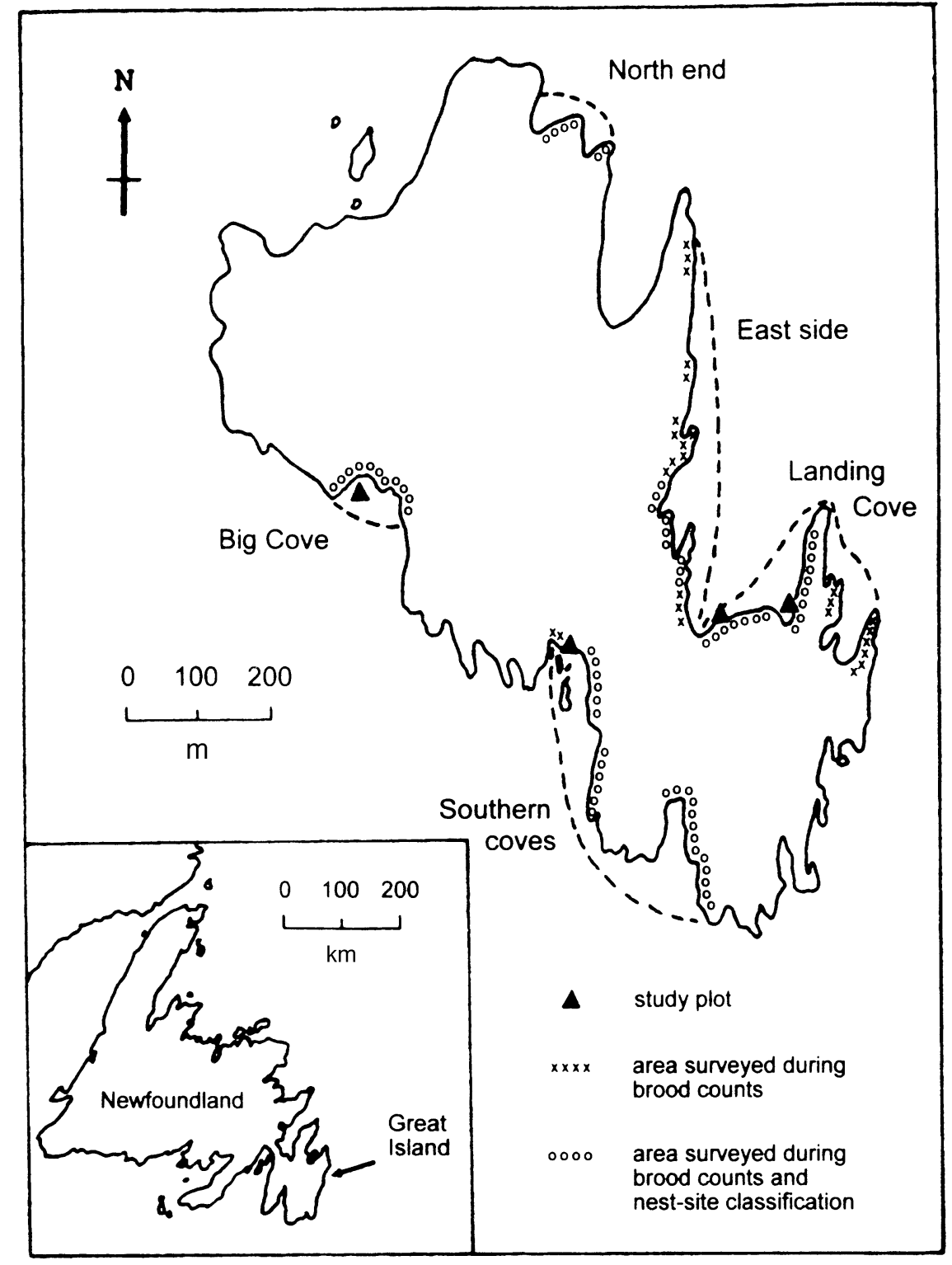

perches on the cliff face and also by soaring alongside cliffs and reaching into nests from the air (Gaston and Nettleship 1981; Regehr 1994).

We examined kittiwake breeding performance in relation to physical and social nest-site characteristics. We predicted that rock protrusions protecting the nest from above and from the sides, and location of nests in dense and central areas (Coulson and Thomas 1985; Porter 1990), would be positively related to success, and that the presence of rock protrusions providing perches for predators below nests would be negatively related to success. Variation in breeding performance in different parts of the island was also considered in terms of large-scale differences in cliff structure.

\section{Methods}

This study was conducted from 28 May to 28 August 1992 and from 4 June to 30 August 1993 on Great Island $\left(47^{\circ} 11^{\prime} \mathrm{N}, 52^{\circ} 46^{\prime} \mathrm{W}\right)$, New- foundland (Fig. 1), where nine seabird species nest, including an estimated 23000 pairs of Black-legged Kittiwakes (Cairns et al. 1989; Rodway et al. 1996).

Kittiwake chicks fledged from very few nests in 1992 and 1993, owing to high predation rates (Regehr and Montevecchi 1997), so we compared the numbers of days eggs or chicks survived (survival duration) among nests. Survival durations were recorded from three study plots on the south side of Great Island in 1992 (Fig. 1). In 1993, these plots were enlarged (from 182 to 381 nests) to increase the potential sample size of chicks, and a fourth plot was added in Big Cove (107 nests; Fig. 1) because breeding success was substantially higher in this area than in others in 1992 (see Results). Nest contents were determined by observation with binoculars or spotting scope from vantage points $10-70 \mathrm{~m}$ from nests every $4 \mathrm{~d}$ or more frequently, weather permitting, throughout incubation (mid-May to mid-July) and chick rearing (mid-June to late August). Survival durations were calculated by subtracting the laying date from the date of death or disappearance of eggs or chicks. When exact dates were not known, midpoints between observations were used. Survival dura- 
tion was measured to a maximum of $70 \mathrm{~d}$, which is the approximate time required for incubation and chick rearing.

The characteristics of nest sites used as explanatory variables were (i) overhangs; (ii) ledges below the nest (underjuts); (iii) vertical barriers adjacent to a nest; (iv) position relative to the periphery of the colony; and $(v)$ density of nests immediately surrounding a nest.

Distances could not be measured directly, so a ranking system was developed for components of four explanatory variables, overhang, underjut, vertical barriers, and position in colony. The width of a kittiwake nest $(\sim 30 \mathrm{~cm})$ provided a scale for horizontal distance out from a cliff face and for vertical distance above or below a nest. Slope away from or toward a nest was ranked for overhang and underjut. The sizes of vertical barriers and distances from the left and right of a nest were ranked. Numbers of nests between a focal nest and the edge of the colony in each of four directions (above, below, left, right) were ranked for position; nests more than $10 \mathrm{~m}$ from other nests were considered to be peripheral. For each variable, rank scores of components were averaged to create a continuous variable. For example, the variable overhang was generated for each nest as an average of the three component ranks: horizontal distance, vertical distance, and slope. This was done because a single value for each explanatory variable represented the level at which conclusions were desired. In addition, preliminary analysis showed that components of variables were highly correlated and a single variable was therefore needed for multiple regression analyses. Density was defined as the number of nests within a $1-\mathrm{m}$ radius of a nest centre $\left(3 \mathrm{~m}^{2}\right)$. Density of neighbouring nests, presence of overhangs and adjacent vertical barriers, absence of underjuts, and central position in the colony were predicted to be positively correlated with survival time of eggs and chicks.

Differences in chick production due to large-scale cliff structure were compared among five regions of Great Island (Fig. 1). Colonywide brood counts were conducted between 7 and 10 August in 1992 and 1993. All nests visible with binoculars or spotting scope from vantage points above cliffs in five regions of Great Island were counted (Fig. 1) and the presence of chicks was recorded. At this time, all chicks were at least $14 \mathrm{~d}$ old and were large enough to be visible in the nest at all times, none had fledged ( $<40 \mathrm{~d}$ old), and most chick deaths had already occurred (see Regehr and Montevecchi 1997). This was considered the late-chick period and was the best time to survey chick production. Although some chicks counted would not have survived to fledging, brood counts provided a comparison of chick production on a colony-wide scale between years.

In 1993, we also compared fine-scale nest-site characteristics between nests that contained chicks and nests that were chosen randomly ("random nests") in the same regions and at the time that brood counts were conducted (Fig. 1). The random sample of nests was chosen from all nests regardless of their reproductive status $(9 \%$ contained chicks and the rest were empty) because we wished to create an unbiased sample to compare with successful nests. Nests were chosen randomly by dividing cliffs into blocks the width of a spotting scope field of view $(15 \times)$, then scoring nests within blocks chosen randomly. Only overhang, density, and position were considered, because analyses from 1992 suggested that these were the most important variables, and so that more nests could be surveyed. In each region, nest-site characteristics were compared between nests with chicks and random nests to determine if chick presence in nests was a chance occurrence or was related to nest-site characteristics.

\section{Analyses}

Survival duration was regressed on overhang, underjut, position in colony, vertical barriers, and density. Partial sums of squares were used to determine if individual explanatory variables were significant predictors of survival duration after the effects of all other variables were removed. Data from 1992 and 1993, and from Big Cove in 1993, were analyzed separately to allow comparisons between years and areas with different breeding success. Overhangs, position relative to the periphery of the colony, and density of nests immediately
Table 1. ANOVA summary table showing the multiple regression of survival duration on overhang $(\mathrm{OH})$, underjut (UJ), position in colony $(\mathrm{P})$, vertical walls $(\mathrm{V})$, and density $(\mathrm{D})$ in $1992(n=111)$ and 1993 ( $n=207)$ for study plots used in both years (south plots).

\begin{tabular}{llrrr}
\hline Source & \multicolumn{4}{c}{ Standard } \\
coefficient & \multicolumn{1}{c}{$F$} & $P$ \\
\hline 1992 & $R^{2}$ & & & \\
OH & 0.07 & 0.284 & 10.96 & 0.001 \\
UJ & 0.00 & -0.034 & 0.17 & 0.680 \\
P & 0.10 & 0.327 & 14.59 & 0.000 \\
V & 0.01 & 0.106 & 1.53 & 0.219 \\
D & 0.12 & -0.359 & 17.09 & 0.000 \\
Full model & 0.29 & & 8.51 & 0.000 \\
1993 & & & & \\
OH & 0.04 & 0.213 & 9.16 & 0.003 \\
UJ & 0.01 & -0.070 & 1.06 & 0.305 \\
P & 0.00 & 0.042 & 0.35 & 0.558 \\
V & 0.02 & 0.146 & 4.25 & 0.040 \\
D & 0.01 & 0.095 & 1.81 & 0.180 \\
Full model & 0.11 & & 4.77 & 0.000 \\
\hline
\end{tabular}

Note: Variance is partitioned into partial sums of squares.

surrounding a nest were compared between nests with chicks and random nests, using ANOVA to test the null hypothesis that nest-site characteristics did not differ between the two groups.

Tolerance for type I error was set at 5\% and residuals were examined to ensure that they met assumptions of the regression analyses. When residuals were not normally distributed or independent, randomization tests were used (Edgington 1980; Sokal and Rohlf 1981; Adams and Anthony 1996). The dependent variable was sampled 500 times, the statistical test was performed each time with the randomized data, and the resulting $F$ ratios were compared with that of the nonrandomized statistical test. The new $P$ value was calculated as the proportion of randomized $F$ ratios exceeding the nonrandomized ratio, i.e., the probability that the observed relationship occurred by chance. When the two $P$ values agree, the original parametric statistic is reported. When the $P$ values are different (one case), the $P$ value from the randomization test is reported as $P_{\mathrm{r}}$.

\section{Results}

The predicted model relating nest-site characteristics to survival duration was significant for nests in the southern study plots checked in both 1992 and 1993 (Table 1). The predicted model was not significant for nests in the additional study plot (Big Cove) in 1993, and no effect of any of the individual nest-site characteristics was detected there $\left(F_{[5,68]}, P>0.2\right)$.

The overall percentage of nests with chicks in the latechick period in the five regions of Great Island was greater in $1993(8.6 \% ; n=6833)$ than in $1992\left(1.8 \% ; n=5365 ; \chi_{1}^{2}=\right.$ 255.9, $P<0.0001)$. Percentages varied among regions, and differences were similar in the 2 years (Fig. 2). Higher percentages of nests with chicks occurred in Big Cove than other regions in $1992\left(\chi_{1}^{2}=204.2, P<0.0001\right)$ and $1993\left(\chi_{1}^{2}=\right.$ 104.3, $P<0.0001$; Fig. 2). Higher proportions of nests with chicks in the late-chick period $(0.82, n=465)$ than random nests $(0.54, n=465)$ had overhangs $\left(\chi_{1}^{2}=82.03, P<0.0001\right)$, and nests with chicks scored significantly higher for overhang than did random nests $\left(t_{1097}=10.32, P<0.001\right.$; Fig. 3$)$. 
Fig. 2. Percentages of kittiwake nests with chicks in five regions of Great Island surveyed during the late-chick period in 1992 and 1993. Numbers above the bars are sample sizes.

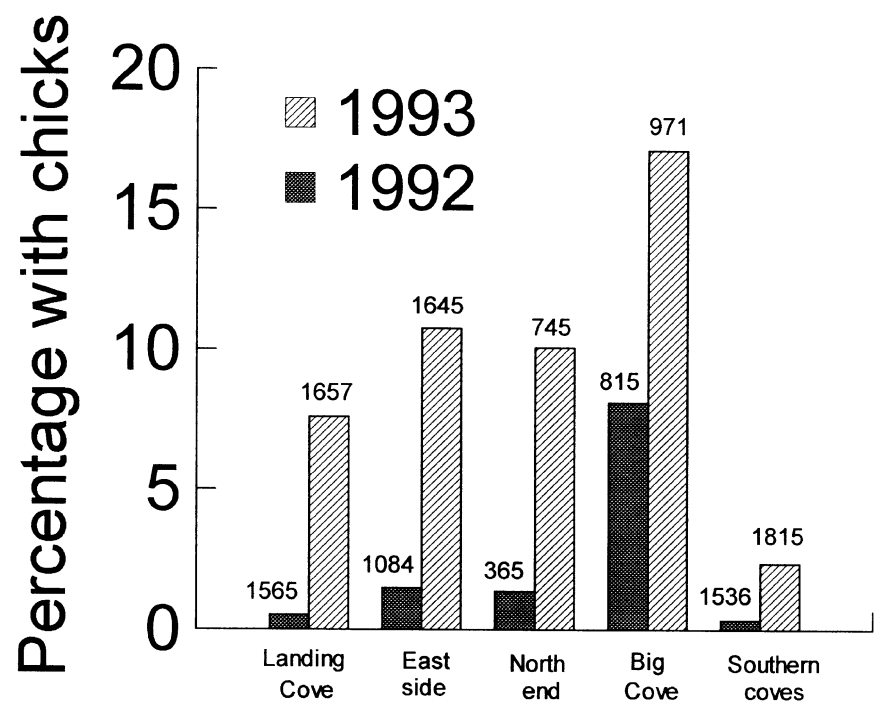

No significant differences in position $\left(P_{r}=0.08, n=930\right)$ or density $\left(t_{928}, P=0.18\right)$ were detected between nests with chicks and random nests.

The percentage of random nests with overhangs differed significantly among regions $\left(\chi_{4}^{2}=6417, P<0.0001\right.$; Fig. 3), ranging from a minimum of $36 \%(n=167)$ in Big Cove to a maximum of $84 \%(n=43)$ in the southern coves. The percentages of random nests with overhangs were $45 \%(n=101)$ in Landing Cove and 65\% $(n=43)$ and $76 \%(n=111)$ at the east side and north end of the island, respectively.

The highest productivity occurred in Big Cove, despite its having the lowest proportion of nests with overhangs, which raised the question of whether large-scale cliff structure or small-scale nest-site characteristics were more important for success. To address this, we compared survival time in all nests in the Big Cove study plot to that in nests with overhangs in all other plots. Survival time in the Big Cove study plot was significantly higher than at nests with overhangs in all other study plots $\left(F_{[1,269]}=10.96, P<0.001\right)$.

\section{Discussion}

Prebreeding kittiwakes evaluate potential nest sites by prospecting, and use information on conspecific breeding success to select nest sites (Danchin and Monnat 1992; Cadiou et al. 1994). The results of this study implicate the significance of large-scale and fine-scale physical features of nest sites selected by Black-legged Kittiwakes. Greater success at nests on a sheer cliff than at nests with overhangs on less sheer, more irregular cliffs suggests that the larger scale cliff structure has greater antipredator benefits. Cliffs with more irregular relief probably provide kittiwakes with more opportunities for fine-scale nest-site selection.

Large-scale cliff structure influenced breeding performance by affecting the behaviour and success of aerial predators. Productivity was highest on sheer cliffs (Big Cove) and lowest on irregular and less steep cliffs. Great Black-backed Gulls had difficulty landing on more regular parts of cliffs and were mobbed more successfully there (H.M.R., personal observations). Similar associations between cliff structure, predation, and breeding success have been found elsewhere (Barrett and Runde 1980; Siegel-Causey and Hunt 1981; Galbraith 1983; Roberts 1988; Chapdelaine and Brousseau 1989).

We found that overhangs above nests were associated with breeding success. These barriers apparently shielded nests from view and access by aerial predators. Vertical barriers adjacent to nests were significantly associated with egg and chick survival duration in 1993 but not in 1992. Paradoxically, irregular cliffs, where nests are more vulnerable to predation, also have the most nest sites with overhangs. Sheer cliffs had proportionately fewer nests with overhangs and had overhangs that were smaller than in other regions.

We were surprised to detect no effect of underjut, because predator perches seemed to be important in facilitating nest predation. Predators were often observed to land on rock protrusions and to use these repeatedly to access nests, but the positions and distances of these perches relative to nests varied. We suspect that our definition of underjut did not characterize predator perches adequately because it excluded predator perches that were not directly below the nest.

Nesting in the centre of the colony or at high density had significant effects on breeding performance in 1992 only. The effect of position on survival duration was positive, as predicted, but the effect of nesting density was negative. These results seem paradoxical; however, owing to the $3-\mathrm{m}^{2}$ scale at which density was measured, small dense clumps of nests could have occurred at any location in the colony and were not confined to central areas. The effect of density may have also been negative because of the small proportion of pairs laying eggs (Regehr and Montevecchi 1997), greatly reducing the effectiveness of swamping and mobbing tactics (see Tenaza 1971; Dexheimer and Southern 1974; Birkhead 1977; Seigel-Causey and Hunt 1981; Parrish 1995; Gaston and Elliot 1996), and because adjacent kittiwake nests also create predator perches. Great Black-backed Gulls often perched on vacated kittiwake nests and used rows of adjacent nests as walkways when hunting on the cliff.

The benefits of different nest-site characteristics may also depend on predator type. Ravens are smaller than Great Black-backed and Herring gulls and appeared to be the most agile nest predators, being able to land on most sites, even wellprotected ones (see also Siegel-Causey and Hunt 1981; Gaston and Elliot 1996). They were often seen landing on sheer cliffs, where Great Black-backed Gulls were never seen hunting. Thus, when ravens rather than Larus spp. are primary predators, fine-scale nest-site characteristics probably provide less antipredator benefit.

If nest-site characteristics such as overhang provide antipredator benefits to kittiwakes, competition among individuals could lead to higher breeding success at high-quality sites even when predation is not occurring. For example, nest-site selection behaviour can lead to competition that results in higher quality breeders nesting in dense colony centres (Coulson and White 1960; Coulson 1968; Falk and Møller 1997). Olsthoorn and Nelson (1990) quantified the physical breeding site characteristics for five seabird species in the absence of predation and found that "roof cover" in kittiwake nest sites was also correlated with breeding success. They 
Fig. 3. Proportions of random nests and nests with chicks with overhangs of different values during the late-chick period in the five regions of Great Island in 1993. Overhang was calculated by averaging values for the three categories width, distance from the nest, and slope (see the text) and ranges from 0 (no overhang) to a maximum of 3.

\section{-Random Nests - Nests with Chicks}

\section{Average overLanding Cove}
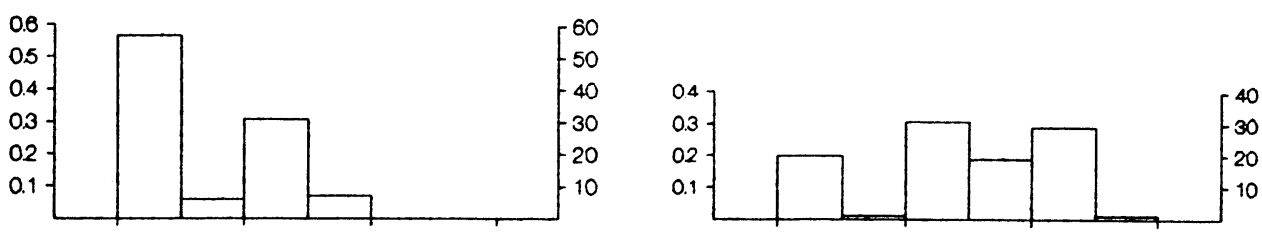

\section{East side}
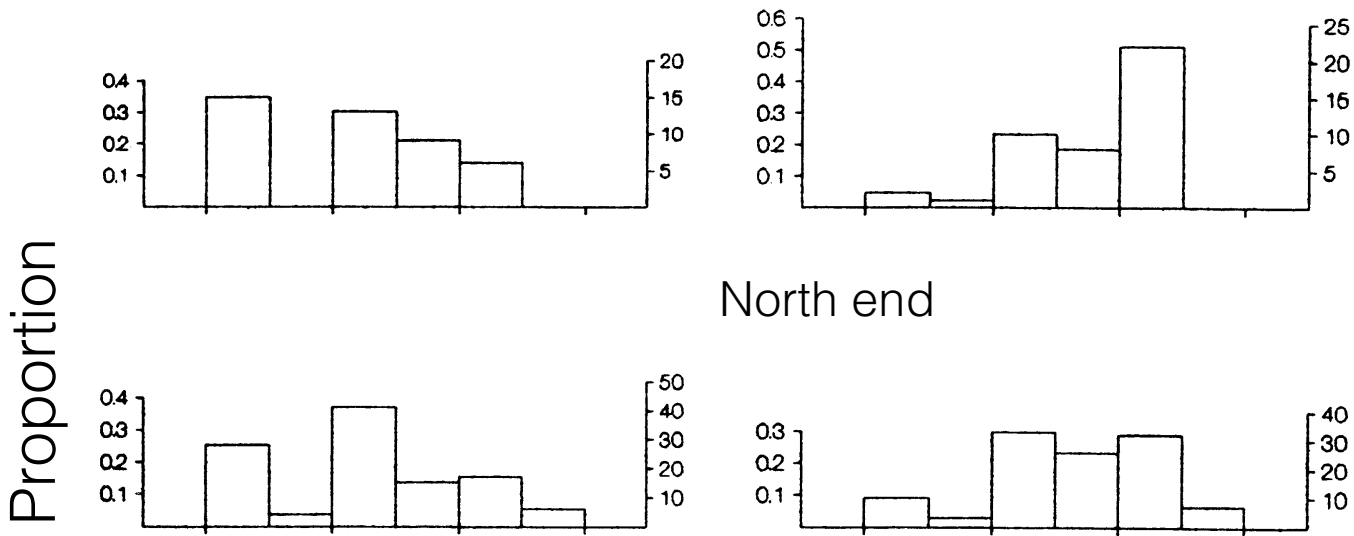

\section{North end}
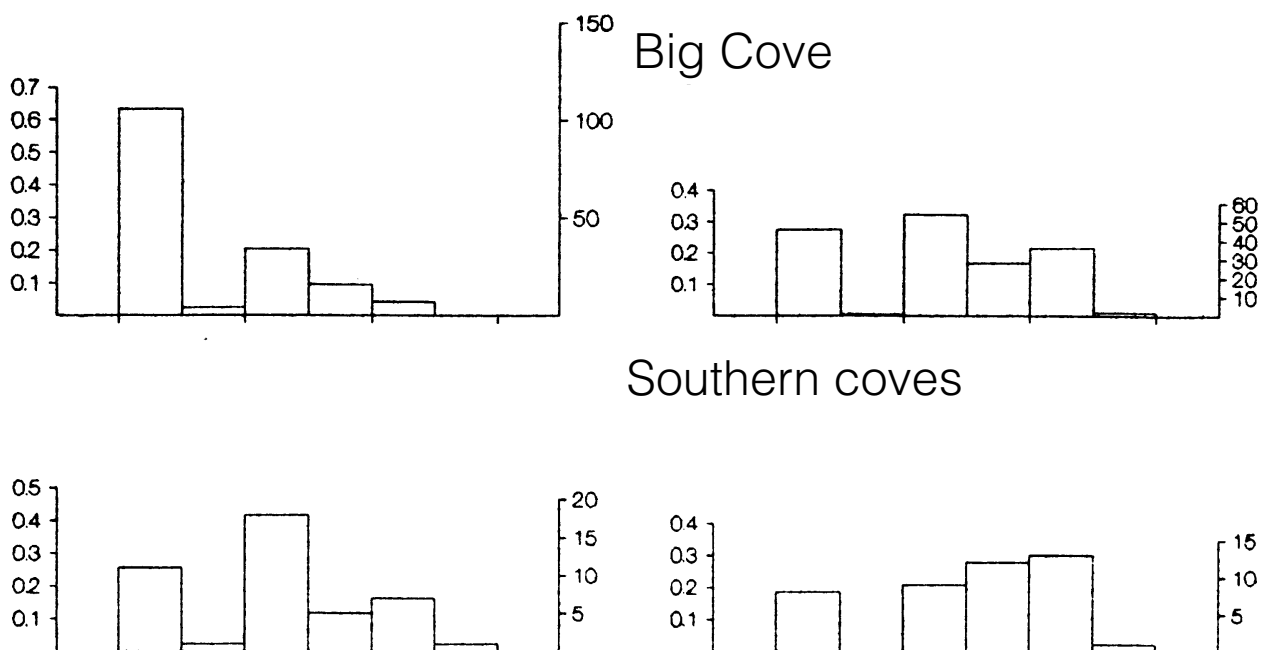

\section{Average overhang score}

suggested that the advantage of roof cover was protection from rain. Alternatively, if predation is the ultimate cause of the preference for nest sites with overhangs, competitive assortment of birds among preferred sites could lead to higher breeding success there, even in the absence of predation.

\section{Acknowledgements}

This study was financed with a Natural Sciences and Engineering Research Council of Canada (NSERC) graduate scholarship (H.M.R.) and an NSERC operating grant and a 
Fisheries and Oceans and NSERC Subvention (W.A.M.). We are grateful to Dave Schneider for help with statistics and for comments on an early version of this paper. John Chardine, Pierre Ryan, Janet Russell, Merrill Francis, and Wayne Lidster helped with field logistics and Donna Butler helped with manuscript preparation. We thank Grant Gilchrist and two anonymous reviewers for helpful reviews of the manuscript. The Reddick family of Bauline provided transportation and radio contact. We thank the Newfoundland and Labrador Parks Division for permission to work on Great Island in the Witless Bay Seabird Ecological Reserve.

\section{References}

Adams, D.C., and Anthony, C.D. 1996. Using randomization techniques to analyze behavioural data. Anim. Behav. 51: 733-738.

Barrett, R.T., and Runde, O.J. 1980. Growth and survival of nestling kittiwakes Rissa tridactyla in Norway. Ornis Scand. 11: 228-235.

Birkhead, T.R. 1977. The effect of habitat and density on breeding success in the Common Guillemot (Uria aalge). J. Anim. Ecol. 46: 751-764.

Buckley, F.G., and Buckley, P.A. 1980. Habitat selection and marine birds. In Behavior of marine animals. Vol. 4. Edited by J. Burger, B.L. Olla, and H.E. Winn. Plenum Press, New York. pp. 69-112.

Cadiou, B., Monnat, J.Y., and Danchin, E. 1994. Prospecting in the kittiwake, Rissa tridactyla: different behavioural patterns and the role of squatting in recruitment. Anim. Behav. 47: 847-856.

Cairns, D.K., Montevecchi, W.A., and Threlfall, W. 1989. Researcher's guide to Newfoundland seabird colonies. Mem. Univ. Nfld. Occas. Pap. Biol. No. 14.

Chapdelaine, G., and Brousseau, P. 1989. Size and trends of Black-legged Kittiwake (Rissa tridactyla) populations in the Gulf of St. Lawrence (Quebec) 1974-1985. Am. Birds, 43: 21-24.

Coulson, J.C. 1968. Differences in the quality of birds nesting in the centre and on the edges of a colony. Nature (Lond.), 217: 478479.

Coulson, J.C., and White E. 1960. The effect of age and density of breeding birds on the time of breeding in the kittiwake Rissa tridactyla. Ibis, 102: 71-88.

Coulson, J.C., and Thomas, C. 1985. Differences in the breeding performance of individual kittiwake gulls, Rissa tridactyla (L.). In Behavioural ecology. Edited by R.M. Sibly and R.H. Smith Blackwell Scientific Publications, Oxford. pp. 489-503.

Cullen, E. 1957. Adaptations in the kittiwake to cliff nesting. Ibis, 99: 275-302.

Danchin, E., and Monnat, J.-Y. 1992. Population dynamics modelling of two neighbouring kittiwake Rissa tridactyla colonies. Ardea, 80: 171-180.

Dexheimer, M., and Southern, W.E. 1974. Breeding success relative to nest location and density in Ring-billed Gull colonies. Wilson Bull. 86: 288-290.

Edgington, E.S. 1980. Randomization tests. Marcel Dekker, New York.

Falk, K., and Møller, S. 1997. Breeding ecology of the fulmar Fulmarus glacialis and the kittiwake Rissa tridactyla in high-arctic northeastern Greenland, 1993. Ibis, 139: 270-281.

Galbraith, H. 1983. The diet and feeding ecology of breeding kittiwakes Rissa tridactyla. Bird Study, 30: 109-120.

Gaston, A.J., and Elliot, R.D. 1996. Predation by ravens Corvus corax on Brunnich's Guillemot Uria lomvia eggs and chicks and its possible impact on breeding site selection. Ibis, 138: 742-798.

Gaston, A.J., and Nettlehship, D.N. 1981. The Thick-billed Murres of Prince Leopold Island. Can. Wildl. Serv. Monogr. Ser. No. 6.

Gochfeld, M. 1980. Timing of breeding and chick mortality in central and peripheral nests of Magellanic Penguins. Auk, 97: 191193.

Hatch, S.A., Byrd, G.V., Irons, D.B., and G.L. Hunt, Jr. 1993. Status and ecology of kittiwakes (Rissa tridactyla and R. brevirostris) in the North Pacific. In The status, ecology and conservation of marine birds of the North Pacific. Edited by K. Vermeer, K.T. Briggs, K.H. Morgan, and D. Siegel-Causey. Spec. Publ., Canadian Wildlife Service, Ottawa, Ont. pp. 140-153.

Lack, D. 1968. Ecological adaptations for breeding in birds. Methuen, London.

Maunder, J.E., and Threfall, W. 1972. The breeding biology of the Black-legged Kittiwake in Newfoundland. Auk, 89: 789-816.

Miyazaki, M. 1996. Vegetation cover, kleptoparasitism by diurnal gulls, and timing of arrival of nocturnal Rhinocerous Auklets. Auk, 113: 698-702.

Montevecchi, W.A. 1978. Nest-site selection and its survival value among Laughing Gulls. Behav. Ecol. Sociobiol. 4: 143-161.

Montevecchi, W.A. 1979. Predator-prey interactions between ravens and kittiwakes. Z. Tierpsychol. 49: 136-141.

Nelson, J.B. 1978. The Sulidae: gannets and boobies. Oxford University Press, Oxford.

Neuman, J.A. 1994. Aspects of the behaviour and ecology of Black-legged Kittiwakes, Rissa tridactyla, breeding at two sites in Newfoundland, Canada, 1990-91. M.Sc. thesis, Memorial University of Newfoundland, St. John's.

Olsthoorn, J.C.M., and Nelson, J.B. 1990. The availability of breeding sites for some British seabirds. Bird Study, 37: 145-164.

Parrish, J.K. 1995. Influence of group size and habitat type on reproductive success in Common Murre (Uria aalge). Auk, 112: 390401.

Porter, J.M. 1990. Patterns of recruitment to the breeding group in the kittiwake Rissa tridactyla. Anim. Behav. 40: 350-360.

Regehr, H.M. 1994. Breeding performance of Black-legged Kittiwakes on Great Island, Newfoundland during periods of reduced food availability. M.Sc. thesis, Memorial University of Newfoundland, St. John's.

Regehr, H.M., and Montevecchi, W.A. 1997. Interactive effects of food shortage and predation on breeding failures of Black-legged Kittiwakes: indirect effects of fisheries activities and implications for indicator species. Mar. Ecol. Prog. Ser. 155: 249-260.

Roberts, B.D. 1988. The behavioral ecology of breeding Black-legged Kittiwakes (Rissa tridactyla) on Middleton Island, Alaska. M.A. thesis, University of California, Santa Barbara.

Rodway, M.S., Regehr, H.M., and Chardine, J.W. 1996. Population census of breeding Atlantic Puffins at Great Island, Newfoundland in 1993-1994. Can. Wildl. Serv. Tech. Rep. Ser. No. 263.

Squibb, R.C., and Hunt, G.L. Jr. 1983. A comparison of nestingledges used by seabirds on St. George Island. Ecology, 64: 727734.

Siegel-Causey, D., and Hunt, G.L. Jr. 1981. Colonial defense behavior in Double-crested and Pelagic Cormorants. Auk, 98: 522-531.

Sokal, R.R., and Rohlf, F.J. 1981. Biometry. Freeman, New York.

Tenaza, R. 1971. Behavior and nesting success relative to nest location in Adelie Penguins (Pygoscelis adeliae). Condor, 73: 81-92.

Wittenberger, J.F., and Hunt, G.L. Jr. 1985. The adaptive significance of coloniality in birds. Avian Biol. 8: 1-78. 